\title{
IMPLEMENTASI METODE QIYASIYAH TERHADAP KEMAMPUAN SANTRI DALAM MEMAHAMI KITAB AL-JURUMIYAH
}

\author{
Mochamad Mu'izzuddin \\ Universitas Islam Negeri Sultan Maulana Hasanuddin Banten \\ Jalan Jendral Sudirman No. 30 Panancangan Cipocok Jaya, Sumurpecung, \\ Kec. Serang, Kota Serang, Banten 42118 \\ e-mail: moch.muizzuddin69@gmail.com
}

\begin{abstract}
Abstrak
Penelitian ini bertujuan untuk mengetahui implementasi metode qiyâsiy di Pesantren Ath-Thahiriyah, mengetahui kemampuan santri memahami Al-Jurumiyah, mengetahui hubungan impementasi metode qiyâsiy dengan kemampuan santri memahami kitab Al-Jurumiyah, dan mengetahui pengaruh implementasi metode qiyâsiy terhadap kemampuan santri memahami kitab Jurumiyah. Metode yang digunakan dalam penelitian ini yaitu survey dengan pendekatan korelasional dan kuasi eksperimen dengan desain Nonequivalent Control Grup Pretest-Postest Design. Populasi dan sampel dalam penelitian ini adalah seluruh santri Pesantren Ath-Thahiriyah Lontar Baru Kota Serang Provinsi Banten yang berjumlah 30 orang. Data penelitian dikumpulkan melalui angket, wawancara, dan tes. Data diolah melalui bantang SPSS versi 16,0. Hasil penelitian menunjukkan bahwa implementasi metode qiyâsiy di pesantren Ath-Thahiriyah Lontar Baru dilaksanakan setiap kajian Al-Jurumiyah yang dinyatakan kategori nilai sering/baik dan nilai rerata persentasenya adalah 50,7\%, kemampuan santri dalam memahami kitab Al-Jurumiyah menunjukkan nilai rerata 86,83 , median 90,75 , dan modus 98,59 yang dikategorikan sangat baik, tidak terdapat hubungan positif dan signifikan antara implementasi metode qiyâsiy dengan kemampuan memahami kitab Jurumiyah sebesar 0,119 , dan memberikan pengaruh positif dan signifikan antara implementasi metode qiyâsiy dengan kemampuan memahami kitab Jurumiyah sebesar 8,20 dan besaran kontribusi variable X terhadap variabel Y sebesar $67,24 \%$, sisanya sekitar $32,76 \%$ dipengaruhi oleh faktor-faktor lainnya yang tidak diteliti.
\end{abstract}

Kata Kunci: Metode Qiyâsiy, Kemampuan Santri, Kitab Jurumiyah 


\section{A. Pendahuluan}

Pesantren merupakan cikal bakal penyelengaraan pendidikan islam yang ada di negara Indonesia. Tercatat dalam sejarah perkembangan agama islam bahwa interaksi antara guru dan murid, dalam hal ini Kyai dan santri mengkaji kitab-kitab klasik atau lebih dikenal dengan sebutan kitab kuning. Pola interaksi sebagai bentuk transformasi ilmu tersebut dapat dilakukan di masjid, musholla, langgar, aula asrama, rumah kiyai, ruang kelas, pendopo, dan lainnya.

Di tengah arus modernisasi dan globalisasi seperti ini, pondok pesantren masih kokoh dan eksis khususnya di Indonesia. Berbeda dengan nasib lembaga pendidikan Islam tradisional di dunia muslim lainnya. Hal tersebut tentu akibat dampak dari semakin gencarnya modernisasi dan pembaharuan yang telah bertransformasi dan berlomba-lomba menjadikannya sebagai pendidikan formal di suatu negara. ${ }^{1}$

Dalam pemahaman yang lebih mendalam, pesantren diartikan oleh $\mathrm{M}$. Dian Nafi' sebagai "suatu lembaga pendidikan dan pengembangan masyarakat, lembaga yang mandiri dan indigenous culture yang berakar di masyarakat." "2 Menurut para sejarawan, pesantren adalah pendidikan tertua apabila dibandingkan dengan lembaga pendidikan yang indigenous (asli) dan tumbuh di Indonesia. Pesantren juga merupakan produk atau hasil budaya bangsa Indonesia. Anggapan tersebut sebab sejak abad ke-13, pondok pesantren yang berbasis masyarakat telah berdiri kokoh di nusantara. ${ }^{3}$

Pembelajaran Jurumiyah merupakan kegiatan belajar mengajar antara santri dan ustadz selaku pengajar dalam perkembangannya sudah cukup tua

\footnotetext{
${ }^{1}$ Azyumardi Azra, Pendidikan Islam: Tradisi dan Modernisasi Menuju Milenium Baru (Jakarta: Logos Wacana Ilmu, 1995), h. 95.

${ }^{2}$ M. Dian Nafi' dkk., Praksis Pembelajaran Pesantren (Yogyakarta: PT. LKiS Pelangi Aksara, 2007), h. iv.

${ }^{3}$ M. Sulthon Masyhud dan M. Khusnurridlo, Manajemen Pondok Pesantren (Jakarta: Diva Pustaka, 2005), h. 1.
} 
sebagai kurikulum utama di kalangan akademisi Islam yang berlangsung sejalan dengan perkembangan masuknya Islam di Indonesia. Pembelajaran alJurumiyah merupakan materi belajar santri yang mengembangkan kompetensi santri pada penguasaan kaidah-kaidah nahwu Fusha sebagai media belajar santri untuk dapat membaca dan memahami kandungan-kandungan kitabkitab klasik yang dipelajari di kalangan pebelajar, kitab-kitab kuning sangat lazim disebut kitab kuning bagi kalangan pebelajar disebabkan kertas kitab yang dicetak oleh penerbit itu berwarna kuning. Ustad dalam istilah pesantren sebagai pendidik membekali santri dengan kajian nahwu diupayakan santri mudah mempelajari kitab-kitab kuning yang notabene berbahasa Arab gundul ${ }^{4}$ yang tidak memiliki harakat dan keragaman struktur nahwu yang menyebabkan kesulitan santri memahami teks-teks nahwu yang ditulis dalam kitab kuning. Kitab nahwu yang diajarkan di pesantren antara lain; kitab jurumiyah, imriti, jami'u durus, dan alfiyah.

Metode qiyasi yang berkembang di pondok pesantren salafi berdasar pada kebermaknaan content yang dapat diaplikasikan bagi santri dan ustad pada kajian ilmu nahwu. Variasi Metode qiyasi yang dikembangkan oleh pondok pesantren salafi masih mempertimbangkan pada kuantitas santri yang nyantri di pesantren tertentu. Pondok pesantren yang kuantitas santrinya lebih dari seratus ratus santri Metode pembelajarannya yang dikembangkan berdasarkan klasikal. Pondok pesantren salafi mengembangkan sistem kelas ini sudah menganut sistem pendidikan modern dengan memperhatikan kemampuan santri terhadap penguasaan santri pada materi nahwu yang dipelajari. Sedangkan pondok pesantren yang kuantitas santrinya kurang dari seratus biasanya menganut Metode pembelajaran halaqah atau bersifat mentoring dalam pengembangan strategi pembelajaran kitab Al-Jurumiyah di pesantren

\footnotetext{
${ }^{4}$ Berbahasa Arab gundul adalah teks nahwu yang tidak memiliki harakat sebagai penanda kaidah nahwu dan tidak memiliki tanda baca nahwu yang sempurna.
} 
Salafi. Problematika kedua Metode qiyasi yang dikembangkan pondok pesantren adalah longgarnya kompetensi penguasaan materi Al-Jurumiyah yang dicapai santri disebabkan lemahnya evaluasi belajar Al-Jurumiyah yang diampu ustad, dan pendidikan pondok pesantren sebagian penyelenggara menganggap sebagai jalur pendidikan nonformal yang tidak terikat dengan legalitas formal pemerintah yang berlangsung lama sejak permulaan Islam datang ke bumi pertiwi Indonesia.

Metode pembelajaran nahwu dilihat dari segi penyampaian materi belajar nahwu secara umum dapat dilakukan atas dasar dua Metode pembelajaran nahwu, yaitu Metode pembelajaran qiyasi dan Metode pembelajaran istiqroiyah (istinbathiyah). Metode pembelajaran qiyasi merupakan Metode pembelajaran nahwu yang berdasarkan atas pembanding kaidah nahwu yang telah memiliki aturan yang baku dengan amtsilah-amtsilah yang menjadi data. Metode pembelajaran nahwu qiyasi didasarkan pada daya nalar induktif dimana Metode ini pembelajaran nahwu qiyasi dari penyampaian materi nahwunya diawali dengan penjelasan ta'rif kaidah nahwu yang baku dilanjutkan dengan pemberian contoh-contoh struktur nahwu yang sesuai dengan ta'rif kaidah nahwu yang baku. Adapun Metode pembelajaran nahwu istiqraiyah (istinbathiyah) berfilosofi pada daya nalar induktif diawali dengan pemberian contoh-contoh sebagai data kemudian dilanjutkan dengan menganalisis data contoh-contoh tersebut melalui identifikasi persamaan dan perbedaannya lalu ditarik kesimpulan dengan pembanding kaidah nahwu yang baku berdasarkan pada ta'rif nahwu yang dipelajari.

Pendekatan pembelajaran nahwu di pondok pesantren dilihat dari segi pemilihan materi nahwu bersifat berkelanjutan dari kitab Al-Jurumiyah yang dipilih oleh Kyai/Ustad, penyampaian isi materi nahwu bersifat abstrak dan teoritis dikaitkan dengan disiplin ilmu pengetahuan al-Qur'ân, pemberian tumpukan informasi pengetahuan nahwu kepada santri sampai saatnya 
diperlukan, keterampilan belajar nahwu yang dikembangkan atas dasar latihan dan hafalan, dan hasil belajar diukur dengan tes lisan, latihan serta hafalan nadhom nahwu pada kitab yang diampu Kyai/Ustad. Pendekatan pembelajaran nahwu di pondok pesantren dilihat dari segi keaktifan belajar santri nampak kegiatan santri menerima informasi pengetahuan materi nahwu secara pasif, perilaku belajar santri pada pembelajaran Al-Jurumiyah dibangun atas kebiasaan, santri tidak melakukan sesuatu yang buruk dalam proses belajar mengajar karena takut akan hukuman yang diberikan Kyai/Ustad. Perilaku belajar yang baik bagi santri berdasarkan motivasi ekstrinsik, dan pengajaran nahwu hanya dilaksanakan di dalam ruang halaqah sebagai majlis ta'lim atau di dalam kelas.

Ada asumsi dari sebagian santri yang berpendapat bahwa kemampuan Santri dalam memahami kitab Al-Jurumiyah masih dirasakan rendah dan proses pembelajaran membuat bosan. Asumsi dari santri ini sebagai indikator lemahnya kompetensi pedagogis ustad pada aspek strategi pembelajaran di kelas. Strategi pembelajaran merupakan kompetensi pedagogic ustad sebagai kemampuan ustad dalam menguasai pengelolaan kelas yang dilakukannya untuk menjadikan pembelajaran secara optimal. Prinsip-prinsip strategi pembelajaran seringkali dilupakan oleh ustad dalam pengelolaan kelas sebagai upaya menciptakan kondisi belajar menyenangkan. Prinsip-prinsip dasar yang sering tidak diperhatikan ustad dalam pengelolaan kelas yang sehat dan kondusif, meliputi; (a) kehangatan dan keantusiasan ustadz dalam mengajar, (b) memberikan berbagai variasi kegiatan, (c) keluwesan, (d) penekanan pada hal positif, dan (e) pengembangan kedisiplinan diri saat menjalankan tugas dan tanggung jawab santri.

Peran kyai/ ustad pada pondok pesantren salafi secara umum belum mendapat prioritas utama sebagai pendidik saat melaksanakan profesinya. Seperti halnya jika ada seorang ustad yang tidak Farhan atau tidak menguasai 
materi yang akan diajarkannya. Seharusnya ustad bisa menjadi fasilitator para santrinya, sehingga didapatkan suasana pembelajaran yang terarah.

Berdasarkan observasi di lapangan, pengajar lebih cenderung dan sering menggunakan metode ceramah namun santri hanyalah pasif. Oleh karenanya santri lebih sering mengalami kebosanan dalam belajar dan cepat lupa apa yang telah didengarkannya. Dengan penjelasan yang lebih detail bahwa saat santri mendengarkan penjelasan pengajar dalam waktu yang lama akan menimbulkan pikiran mereka yang tidak fokus. Sehingga tingkat ketercapaian hasil pembelajaran tidak melampaui target. Dengan demikian, perlunya peneliti untuk mengangkat permasalahan yang telah disebutkan diatas tentang implementasi metode qiyasiyah terhadap kemampuan santri dalam memahami kitab Al-Jurumiyah di pondok pesantren salafi At-Thohiriyah Kota Serang.

Terkait dengan persoalan Implementasi Metode Qiyasiyah terhadap Kemampuan Santri dalam Memahami Kitab Al-Jurumiyah, beberapa penelitian atau kajian telah dilakukan, diantaranya adalah sebagai berikut;

1) Pengaruh Metode Deduktif dengan Menggunakan Media Kartu dalam Memahami “Jumlah Fi'liyah" (Ma'had Al-Jami'ah IAIN Syekh Nurjati Cirebon) oleh: Neli Sa'adah, Khasan Aedi. Penelitian tersebut bertujuan untuk mengetahui peningkatan Kemampuan mahasantri dalam memahami kaidah Nahwu pada materi "Jumlah Fi'liyah" dengan menerapkan metode deduktif menggunakan media kartu terhadap mahasantri Ma'had Al-Jami'ah IAIN Syekhnurjati Cirebon. Hasil penelitian menunjukan adanya pengaruh metode deduktif dengan menggunakan media kartu dalam memahami “jumlah Fi'liyah” di kelas eksperimen ma'had al-Jami'ah IAIN Syekh Nurjati Cirebon. ${ }^{5}$

\footnotetext{
${ }^{5}$ Neli Sa'adah dan Khasan Aedi, “Pengaruh Metode Deduktif dengan Menggunakan Media Kartu dalam Memahami Jumlah Fi'liyah (Mahasantri Ma'had Al-Jami'ah IAIN Syekh Nurjati Cirebon)," El-Ibtikar 7, no. 2 (2018), https://doi.org/10.24235/ibtikar.v7i2.3335.
} 
2) Pengembangan Model Pembelajaran Qawaid Sharraf dengan Pendekatan Qiyasiyah di MTs Negeri Sumber Bungur Pamekasan. Oleh: Achmad Muhlis. Kajian tersebut difokuskan yaitu mendiskripsikan model pembelajaran, respons peserta didik dan beberapa faktor yang memberikan pengaruh dalam pengembangan model pembelajaran qowaid shorof dengan metode qiyasiyyah. Adapun hasil penelitiannya menyebutkan bahwa pengembangan model pembelajaran qowaid shorof dengan metode qiyasiyyah dibangun dari 4 model pembelajaran yang dapat diterapkan sehingga mencapai belajar mengajar yang maksimal. ${ }^{6}$

3) Pesantren Tradisional sebagai Basis Pembelajaran Nahwu dan Sharaf dengan Menggunakan Kitab Kuning. Oleh: Aliyah. Penelitian ini menggunakan metode literatur, dengan meneliti beberapa sumber yang berkaitan dengan pesantren dan pembelajaran nahwu shraf dengan memakai kitab kuning. Penelitian ini menyimpulkan bahwa pesantren pada masa awal kemunculan memang sebagai pusat pengembangan ilmu agama yang berasal dari berbagai kitab bahasa Arab atau bisa. Di pondok pesantren pembelajaran nahwu dan sharaf merupakan dasar dari pengetahuan pertama yang diajarkan karena dengan pengetahuan tersebut menjadi modal awal bagi santri dalam memahami kitab-kitab lainnya. ${ }^{7}$

Perbedaan penelitian ini dengan kajian-kajian yang sudah dilaksanakan yaitu bahwa penelitian ini terfokus atau terbatas pada aspek implementasi atau penerapan metode qiyasiyah terhadap kemampuan santri dalam memahami

\footnotetext{
${ }^{6}$ Achmad Muhlis, "Pengembangan Model Pembelajaran Qawaid Sharraf dengan Pendekatan Qiyasiyah di MTs Negeri Sumber Bungur Pamekasan," NUANSA: Jurnal Penelitian IImu Sosial dan Keagamaan Islam 13, no. 1 (2016), https://doi.org/10.19105/nuansa.v13i1.920.

7 Aliyah Aliyah, "Pesantren Tradisional Sebagai Basis Pembelajaran Nahwu Dan Sharaf Dengan Menggunakan Kitab Kuning," Al-Ta'rib: Jurnal Ilmiah Program Studi Pendidikan Bahasa Arab IAIN Palangka Raya 6, no. 1 (2018), https://doi.org/10.23971/altarib.v6i1.966.
} 
kitab Al-Jurumiyah. Hal ini penting dikaji, karena untuk mengetahui akar persoalan mengenai metode efektif yang dapat dipergunakan dalam pembelajaran kitab Al-Jurumiyah di pondok pesantren. Hal yang lainnya yaitu menginventarisasi pengetahuan tentang Metode-Metode qiyasi yang dikembangkan di pesantren salafi At-Thahiriyah Kota Serang, memahami beberapa pendekatan pembelajaran Al-Jurumiyah yang sesuai dengan setrategi pembelajaran nahwu, prinsip-prinsip pembelajaran nahwu, dan penerapan teknik pembelajaran yang sesuai dengan karakter materi AlJurumiyah

Penelitian ini bermanfaat dalam mengisi kekurangan kajian pengembangan Metode qiyasi dan kompetensi pembelajaran nahwu berkenaan dengan hasil mengajar kyai/ Ustadz antara teori dan praktek, yang hingga kini masih belum dikaji secara mendalam. Kajian ini dapat pula memberikan pengetahuan tentang peranan kyai/ ustad dalam pembelajaran, pendekatan pembelajaran yang dikembangkan pada kegiatan belajar nahwu, metode pembelajaran, prinsip-prinsip pembelajaran yang dikembangkan pada Metode pembelajaran yang serasi dengan pembelajaran nahwu, dan penerapan teknik pembelajaran nahwu yang tepat, serta identifikasi kemampuan pembelajaran santri sebagai ketercapaian hasil mengajar kyai/ustad.

\section{B. Deskripsi Teoritis}

1. Hakikat Metode Qiyasi

Pada bahasa Bloom, belajar merupakan "perubahan tingkah laku baik yang menyangkut pengetahuan, keterampilan dan sikap”. Belajar secara mendalam dapat diartikan sebagai berubahnya perilaku sebagai wujud perubahan tatanan hati yang seimbang. ${ }^{8}$ Sedangkan Westphal

\footnotetext{
${ }^{8}$ Akhmad Sodiq, Bahan Ajar PLPG: Metodologi Pembelajaran Agama Islam (Jakarta:
} FITK UIN Syarif Hidayatullah, 2011), h. 17. 
(1979) berpendapat bahwa metode merupakan rangkaian dari unsurunsur silabus, pendekatan, strategi/ teknik, bahan/materi dan gaya pengajar. ${ }^{9}$

Pendapat yang dikemukakan oleh Richards dan Rodgers (1986), menerangkan bahwa Metode merupakan seperangkat rancangan pengajaran yang terdiri dari pendekatan, rancang bangun dan prosedur. ${ }^{10}$ Pada penggunaan metode al-Tharîqah al-Qiyâsiyyah, yang mana metode tersebut merupakan pembelajaran nahwu yang diawali dari kaidah nahwu/ sharaf terlebih dahulu, kemudian dilanjutkan dengan berbagai contoh yang mampu menjelaskan kaidah yang sudah diajarkan. Model pembelajaran dengan metode ini cenderung diarahkan pada penghafalan dan pemahaman terhadap nahwu terlebih dahulu melewati ta'rif (pendefinisian) dan al-mabda' al-âmm (prinsip umum), ${ }^{11}$ yang selanjutnya ditindak lanjuti dengan memberikan berbagai contoh kalimat yang berhubungan, dan mengaplikasikan kaidahnya. ${ }^{12}$ Pola berpikir yang dikembangkan

\footnotetext{
${ }^{9}$ Patricia Westphal dalam Teaching and Learning a Key to Succes mengutip June K.
} Philips, Building on Experence, Building for Succes (Lincolnwood: National Teks Book, 1979), h. 120.

10 Jack C. Richards dan Theodore S. Rodgers, Approaches and Methods in Language Teaching: A Description and Analysis (Cambridge University Press, 1986), h. 28.

${ }^{11}$ Metode ini dari sudut pandang psikologi sesuai dengan teori Gestalt (Gestalt Theory), bahwa pembelajar itu cenderung melihat dan mempersepsi sesuatu sebagai keseluruhan atau secara umum, tanpa terlebih dahulu melihat rinciannya. Keseluruhan ini bukan sekedar sekumpulan dari bagian-bagiannya, melainkan merupakan sistem yang unsur-unsurnya saling berkaitan secara terpadu. Keseluruhan itu, menurut logika, mendahului (ada lebih dahulu daripada bagian-bagiannya). Belajar bahasa, dengan demikian, didasarkan pada pemahaman relasi antara berbagai unsur-unsurnya, rekonstruksi, dan memanfaatkan pengalaman masa lalu dalam rangka menafsirkan dan memahami sesuatu yang baru dan dalam situasi yang baru pula. Lebih lanjut lihat: 'Abd al'Aziz ibn Ibrahim al-Ushaili, al-Nazhariyyat al-Lughawiyyah wa al-Nafsiyyah wa Ta'lim alLughah al-'Arabiyyah (Riyadh: Maktabah al-Malik Fahd al-Wathaniyyah, 2000), h. 65-66.

${ }^{12}$ Mahmud Rusydi Khithir, Thuruq Tadris al-Lughah al-'Arabiyyah wa al-Tarbiyah alDiniyyah fi Dhau'i al-Ittijahat al-Haditsah (Kairo: Daar al-Ma'rifah, 1983), h. 215. 
model pembelajaran adalah pola berpikir deduktif (bertitik tolak dari umum ke khusus atau parsial).

Menurut pendapat Ahmad Fuad Effendy dalam buku yang berjudul Metodologi Pengajaran Bahasa Arab menyatakan bahwasanya metode pengajaran tata bahasa bertujuan sebagai penunjang tercapainya kemahiran berbahasa. Pada dasarnya,kegiatan tata bahasa terdiri dari dua bagian: (a) pengenalan kaidah-kaidah bahasa dan (b) pemberian latihan atau drill. Kedua kegiatan tersebut dapat dilaksanakan dengan dua cara: deduktif (qiyasiyyah) dan induktif (istiqro'iyyah). ${ }^{13}$

Dan menurut Muhbib Abdul Wahab dalam bukunya yang berjudul Epistimologi dan Metodologi Pembelajaran menerangkan bahwa setiap bahasa pasti mempunyai aturan atau kaidahnya sendirisendiri. Kaidah bahasa Arab timbul tidak berbarengan dengan timbulnya bahasa Arab itu sendiri, melainkan muncul sesudah bahasa Arab dipergunakan didalam kehidupan sosial. Adanya tata bahasa arab, tentu saja di latar belakangi oleh adanya kesalahan berbahasa atau biasa disebut lahn. Hal ini menunjukkan bahwa pembelajaran qawa'id harus berorientasi kepada penggunaan bahasa Arab itu sendiri, bukan semata-mata belajar dan menghafal kaidah, tanpa dibarengi dengan aplikasinya secara nyata. Nahwu-sharf disusun tak lain supaya orang yang memakainya tidak melakukan kesalahan saat dalam berbicara maupun menulis bahasa Arab. ${ }^{14}$

Menurut pendukungnya, metode tersebut terlihat sederhana, mudah serta cepat dipahami dan diterapkan untuk membaca atau

${ }^{13}$ Ahmad Fuad Effendy, Metodologi Pengajaran Bahasa Arab (Malang: Misykat, 2009), h. 106.

${ }^{14}$ Muhbib Abdul Wahab, Epistimologi dan Metodologi Pembelajaran Bahasa Arab (Jakarta: Lembaga Penelitian UIN Syarif Hidayatullah, 2008), h. 175. 
membuat kalimat baru. Akan tetapi, bagi penentangnya, metode ini dianggap tidak bermakna dalam pembelajaran nahwu, karena peserta didik diminta untuk menghafalnya. Yang lebih kurang bermakna adalah model penghafalan dan imitasi "buta" tanpa dibarengi dengan pemahaman (al-muhakat al- 'amya'). ${ }^{15}$ Metode ini dianggap sebagai penyebab lemahnya peserta didik dalam berbahasa Arab, karena peserta didik lebih banyak dilatih untuk menirukan dan menganalogikan. Metode ini dinilai "membunuh" kreativitas dan kebebasan peserta didik dalam berpendapat. ${ }^{16}$

Metode yang dianggap paling tua ini barangkali kurang tepat diterapkan untuk para pemula, karena akan mengalami kesulitan dalam memahaminya. Karena itu, jika hendak digunakan, metode ini lebih cocok untuk peserta didik tingkat Madrasah 'Aliyah, Perguruan atau Pendidikan Tinggi, dan yang sudah banyak memiliki dasar-dasar kaidah. Sebaliknya metode ini kurang cocok digunakan untuk tingkat dasar atau pemula (marhalah ibtidâtyyah). Di antara buku nahwu yang disusun berdasar pada metode tersebut yaitu Jami' al-Durûs al'Arabiyyah karya Mushthafâ al-Ghalâyainî ${ }^{17}$ (1885-1944).

\footnotetext{
${ }^{15}$ Khithir, Thuruq Tadris al-Lughah al-'Arabiyyah wa al-Tarbiyah al-Diniyyah fi Dhau'i al-Ittijahat al-Haditsah, h. 216.

${ }^{16}$ Rusydi Ahmad Thu'aimah dan Muhammad al-Sayyid Manna', Tadris al-'Arabiyyah fii al-Ta'liim al-'Amm: Nazhariyyat wa Tajarib (Kairo: Daar al-Fikr al-'Arabii, 2000), h. 61-62.

${ }^{17}$ Mushthafâ al-Ghalâyainî dianggap sebagai tokoh nahwu abad kedua puluh, karena karya yang cukup populer, Jâmi' al-Durûs al-'Arabiyyah. la lahir di Beirût Lebanon pada 1885. la pernah belajar langsung di Masjid al-Azhar Mesir kepada Muhammad 'Abduh (w. 1905) dan pemikirannya banyak dipengaruhi oleh tenaga pendidiknya. Secara otodidak ia juga mempelajari pemikiran Muhammad Rasyîd Ridhâ dalam majalah al-Manâr, dan 'Abd alRahmân al-Kawâkibî dalam bukunya, Umm al-Qura dan Thaba'i al-Istibdâd. la menekuni profesi sebagai pengajar bahasa Arab dan sejarah Islam. la pernah terjun di dunia politik untuk melawan penjajahan Perancis atas negaranya. la sempat ditangkap dan dipenjara oleh pemerintah kolonial selama 15 hari pada tahun 1922, lalu dibuang ke Palestina. Di antara karyanya adalah Nazharât fi al-Lughah wa al-Adab, al-Islâm Rûh al-Madaniyyah, Rijâl alMu'allaqât al-Asyr, 'Idhat al-Nâsyiîn, Sullam al-Durûs al-'Arabiyyah, al-'Ilm wa al-Dîn, dan Nukhbah min al-Kalâm al-Nabawî. Selain pernah menjabat sebagai anggota Dewan Ilmiah di
} 
2. Hakikat Kemampuan Santri dalam Memahami Kitab Al-Jurumiyah

Kemampuan santri dalam memahami kitab Al-jurumiyah merupakan refleksi keluasan, kedalaman, dan kerumitan (secara bertingkat), yang digambarkan secara jelas dan dapat diukur dengan teknik-teknik penilaian tertentu. Kompetensi belajar santri menentukan apa yang harus dilakukan peserta didik untuk mengerti, menggunakan, menjelaskan, mengapresiasi atau menghargai. Indikator evaluasi hasil belajar Al-Jurumiyah dapat digunakan sebagai dasar penilaian terhadap pendidik dalam mencapai pembelajaran dan kinerja yang diharapkan. Indikator kemampuan santri dalam memahami kitab Al-Jurumiyah merupakan uraian hasil belajar yang telah dikuasai santri dalam pembelajaran.

Penilaian terhadap evaluasi kemampuan santri dalam memahami kitab Al-Jurumiyah merupakan salah satu kegiatan yang harus dilakukan kyai/ustad dalam kegiatan pembelajaran. Dengan penilaian, ustad akan mengetahui perkembangan proses dan hasil belajar santri, intelegensi, bakat khusus, minat, hubungan sosial, sikap dan kepribadian santri. Penilaian pemahaman kitab Al-Jurumiyah merupakan suatu proses pengumpulan, pelaporan, dan penggunaan informasi tentang proses dan hasil belajar peserta didik atau pelaporan umpan balik terhadap hasil mengajar ustad dengan menerapkan prinsip-prinsip penilaian, pelaksanaan berkelanjutan, bukti-bukti autentik, akurat, dan konsisten, serta mengidentifikasi pencapaian kompetensi dan hasil belajar atau informasi hasil mengajar ustad pada mata pelajaran nahwu yang dikemukakan melalui pernyataan yang jelas tentang standar yang harus dan telah dicapai.

Damaskus pada 1927, ia juga pernah menjadi mufti Lebanon. Lihat Ahmad al-Khush, alGhalayaini Nahwiyyu al-'Ashr (Damaskus: al-Mathba'ah al-'Ilmiyyah, 1988), h. 23. 


\section{Metode Penelitian}

Metode penelitian ini adalah metode ekspository survey terhadap Metode qiyasi di pondok pesantren salafi dalam kajian pendekatan dan evaluasi hasil belajar Al-jurumiyah dilihat dari kemampuan santri dalam memahami kitab Al-Jurumiyah. Pada penelitian ini dipergunakan pendekatan kualitatif dan kuantitatif.

Adapun populasi penelitian ini yaitu seluruh santri di pondok pesantren salafi At-Thahiriyah Kota Serang, sedangkan sampel penelitian ini yaitu Santri, sejumlah 30 santri yang dipilih berdasarkan random sampling Purposive.

Teknik pengumpulan data yang dilaksanakan untuk melengkapi penelitian ini yaitu sebagai berikut: (a) Kajian pustaka dipergunakan sebagai pelengkap data teoritik tentang metode qiyasi dan kemampuan Santri dalam memahami kitab Al-Jurumiyah. (b) Observasi di mana peneliti melaksanakan pengamatan langsung pada proses kegiatan belajar mengajar mata pelajaran kitab Al-Jurumiyah dengan memperhatikan proses pembelajarannya dan hasil mengajar kyai/ ustadz sebagai tindakan penelitian awal. (c) Wawancara, di mana peneliti melakukan wawancara kepada responden mengenai analisis peran kyai/ustad nahwu dalam pembelajaran dan Metode qiyasi dan kemampuan santri dalam memahami kitab Al-Jurumiyah sebagai evaluasi hasil belajar kitab nahwu. (d) Angket, di mana teknik pengumpulan data ini dilaksanakan dengan menyebarkan angket pada responden santri kepada Metode qiyasi yang dilakukan kyai/ustad dalam pembelajaran, dan (e) Test, di mana, teknik pengumpulan data tersebut dilaksanakan dengan menghimpun nilai kemampuan santri dalam memahami kitab Al-Jurumiyah hasil belajar santri dalam mata pelajaran nahwu yang ada pada hasil tes nahwu di Pondok Pesantren Salafi At-Thahiriyah. Kota Serang. 


\section{Hasil dan Pembahasan}

Dari hasil Penelitian menjelaskan implementasi metode qiyâsiy yang dikembangkan di Pesantren Salafi At-Thahiriyah Kota Serang dalam meningkatkan kemampuan santri dalam memahami kitab Al-Jurumiyah di Pesantren Al-Thahiriyah Lontar Baru Kagungan Kota Serang.

\section{Implementasi Metode Qiyâsiy}

Dari hasil wawancara dengan ustad yang mengampu kitab AlJurumiyah bahwa Pelaksanaan metode qiyâsiy diselenggarakan setiap kajian nahwu dalam mempelajari kitab Al-Jurumiyah yang waktu mempelajarinya setelah shalat fardhu magrib di kelas 1 level takmili. Pengujian metode ini dilakukan pada santri yang sudah di kelas 2 takmili di pondok pesantren Al-Thahiriyah agar kevalidan data dapat diakui kesahihannya yang telah mengenal langkah-langkah pengajaran nahwu pada kitab Al-Jurumiyah yang melekat proses pembelajaran menggunakan metode qiyâsiy (deduktif). Langkah-langkah yang dilakukan kyai/ustadz, antara lain: penekanan hafalan kaidah nahwu, diikuti pemahaman kaidah nahwu, pemberian contoh kaidah nahwu dalam tataran bahasa Arab yang digunakan, menyimpulkan secara general dari hasil pemahaman tentang contoh kaidah bahasa Arabnya yang dipahami santri dan kyai/ustadz secara bersama-sama, dan latihan-latihan.

Dari hasil penelitian dari data instrumen angket implementasi metode qiyâsiy di pesantren salafi At-Thahiriyah Kota Serang didapat data meliputi metode qiyâsiy dilaksanakan ketika mengaji kitab Al-Jurumiyah. Dalam pelaksanaan metode qiyâsiy pada pengajian Al-Jurumiyah yang dilakukan Kyai/ Ustadz di pondok pesantren Al-Thahiriyah didapat secara umum rerata dalam kategori baik atau sering dalam tahapan-tahapan pembelajaran Al-Jurumiyah yang berdasar teori metode qiyâsiy dengan nilai rerata 55,67 lihat di tabel 4.2 di atas. Kriteria nilai tersebut berada 
pada posisi 46 - 60, maka nilai 55,6 dapat dinyatakan kategori nilai: sering/baik dan nilai rerata persentasenya adalah 50,7\%.

Adapun hasil uji analisis parsial dalam perhitungan statistik dari data implementasi metode qiyâsiy sebagai variabel (X) yang merupakan variabel bebas ini dapat ditemukan nilai Mean sebesar 55,56, Median sebesar 55,23, dan modus sebesar 54,57.

Sedangkan uji persyaratan normalitas dari data variabel $(\mathrm{X})$ yang telah dipaparkan tersebut di atas menunjukan variabel (X) tentang implementasi metode berdistribusi normal dengan nilai tabel dengan taraf Signifikansi $5 \%(0,95: 3)$ dan dk 3 dalam daftar chi kuadrat diperoleh harga $\alpha^{2}(0,95: 3)=7,815$. Menentukan uji normalitas data variabel berdasarkan hasil uji normalitas di atas $\alpha^{2}$ hitung $=239,1007$ lebih besar dari $\alpha^{2}$ tabel, maka dapat disimpulkan keberartian dari sampel yang berasal dari populasi yang berdistribusi normal .

Dengan demikian dapat disimpulkan bahwa implementasi metode qiyâsiy dapat dilaksanakan kyai/ustadz di pondok Ath-Thohiriyah kota Serang dengan kategori baik atau sering dan uji persyaratan data variabel (X) berdistribusi normal, didukung oleh pendapat Soedijarto yang dikutip M. Hosnan bahwa metode qiyâsiy mempunyai kedudukan yang strategis dalam pencapaian mutu pendidikan. Peran pengajar sebagai pengelola proses pembelajaran begitu menentukan kualitas hasil belajarnya. ${ }^{18}$

Dari pemaparan tersebut bisa disimpulkan bahwa implementasi metode qiyâsiy ini bisa dinilai dengan kategori baik dan sering dilakukan oleh ustadz dalam proses pembelajaran nahu, dan skenario pembelajaran nahwu pada kajian kitab Al-Jurumiyah kecenderungannya menggunakan metode qiyâsiy yang melekat.

${ }^{18}$ M. Hosnan, Pendekatan Saintifik dan Kontekstual dalam Pembelajaran Abad 21: Kunci Sukses Implementasi Kurikulum 2013 (Bogor: Ghalia Indonesia, 2014), h. 437. 


\section{Kemampuan Santri dalam Memahami Kitab Al-Jurumiyah}

Hasil pengujian analisis parsial dari kemampuan santri dalam memahami kitab Al-Jurumiyah dalam tabel di atas menunjukkan nilai rerata sebesar 86,83, median sebesar 90,75, dan modus sebesar 98,59. Hal ini berarti bahwa kemampuan santri dalam memahami kitab AlJurumiyah dapat dikategorikan sangat baik atau sangat tinggi kemampuannya. Keberartian kemampuan santri dalam memahami kitab Al-Jurumiyah ini bisa saja dipengaruhi oleh keberhasilan kyai/ustad dalam memberikan penjelasan materi nahwu pada proses belajar mengajar kitab Al-Jurumiyah yang baik sehingga hasil tes pemahaman kitab Al-Jurumiyah sangat sempurna.

Adapun hasil uji persyaratan normalitas data variabel (Y) tentang kemampuan santri dalam memahami kitab Al-Jurumiyah dilakukan dengan uji chi kuadrat pada penjelasan hasil penelitian menunjukkan bahwa tabel dengan taraf signifikansi $5 \%(0,95: 5)$ dan dk 5 dalam daftar chi kuadrat diperoleh harga $\alpha^{2}(0,95: 5)=11,070$. Menentukan uji normalitas data variabel berdasarkan hasil uji normalitas di atas $\alpha^{2}$ hitung $=454.8075$ lebih besar dari $\alpha^{2}$ tabel, maka dapat disimpulkan keberartian dari sampel yang berasal dari populasi yang berdistribusi normal.

Dengan demikian hasil pengujian uji parsial pada variabel (Y) tentang kemampuan santri dalam memahami kitab Al-Jurumiyah ini dapat diartikan sangat baik dan perlu diuji lanjut tentang kebenaran apakah terdapat hubungan signifikan antara implementasi metode qiyâsiy dengan kemampuan santri dalam memahami kitab Al-Jurumiyah. Apabila uji korelasi dari dua variabel tersebut menunjukkan hubungan yang tidak signifikan antara kedua variabel tersebut, berarti ada variabel lain yang signifikan terhadap variabel (Y). Hal ini perlu adanya penelitian lanjutan. 


\section{Hubungan Implementasi Metode Qiyâsiy dengan Kemampuan} Santri dalam Memahami Kitab Al-Jurumiyah

Hasil pengujian hipotesis hubungan implementasi metode qiyâsiy dengan kemampuan santri dalam memahami kitab Al-Jurumiyah signifikan serta memiliki koefisien korelasi $r_{y}$. Sebesar 0,119 dan koefisien determinasi $\mathrm{r}_{\mathrm{y}}{ }^{2}=0,63$ maka $0,63^{2} \times 100 \%=0,01 \%$. Hal ini berarti implementasi metode qiyâsiy mempunyai hubungan sebesar 0,01\% dengan naik turunnya kemampuan santri dalam memahami kitab Al-Jurumiyah tidak ada hubungannya yang signifikan dengan implementasi metode qiyâsiy dalam pembelajaran kitab Al-Jurumiyah.

Ternyata berdasarkan temuan tersebut, implementasi metode qiyâsiy mempunyai hubungan sebesar $0,01 \%$ saja, sedangkan sisanya dipengaruhi beberapa faktor lain yang tidak diteliti pada penelitian kali ini. Maka kesimpulannya bahwa makin baik implementasi metode qiyâsiy tidak ada hubungannya dengan naik kemampuan santri dalam memahami kitab Al-Jurumiyah dan sebaliknya makin tidak baik implementasi metode qiyâsiy tidak ada hubungannya dengan semakin rendahnya kemampuan santri dalam memahami kitab Al-Jurumiyah. Hasil penelitian ini menginformasikan bahwa implementasi metode qiyâsiy tidak berhubungan secara positif dan signifikan dengan kemampuan santri dalam memahami kitab Al-Jurumiyah di Pesantren Al-Thahiriyah Lontar Baru kota Serang Provinsi Banten.

\section{Pengaruh Implementasi Metode Qiyâsiy terhadap Kemampuan} Santri dalam Memahami Kitab Jurumiyah

Hasil pengujian hipotesis pengaruh perbedaan dari implementasi metode qiyâsiy dengan kemampuan santri dalam memahami kitab AlJurumiyah dengan melalui uji pre-test dan post-test atas kemampuan santri dalam memahami kitab Al-Jurumiyah yang dipengaruhi oleh 
implementasi metode qiyâsiy ini menunjukkan nilai korelasi 0,219, dan taraf signifikansinya sebesar 0,244 , dan hasil pengujian uji th (t hitung): sebesar 8,20. Sedangkan dalam diperoleh $\mathrm{tt}(\mathrm{t}$ tabel) sebesar 1,70, berarti t hitung lebih besar daripada $\mathrm{t}$ table (th $8,20>\mathrm{tt} 1,70$ ), maka terdapat pengaruh perbedaan yang signifikan antara variabel $\mathrm{X}$ dengan variable $\mathrm{Y}$. Berdasarkan perhitungan tersebut di atas, maka diterima (Ho) hipotesis yang tidak terdapat pengaruh perbedaan yang signifikan antara variabel $\mathrm{X}$ dengan variabel $\mathrm{Y}$ dan ditolak (Ha) hipotesis kerja yang menyatakan terdapat pengaruh yang signifikan antara variabel $\mathrm{X}$ dengan variable $\mathrm{Y}$.

Ternyata berdasarkan temuan tersebut menunjukkan pengaruh implementasi metode qiyâsiy terhadap kemampuan santri dalam memahami kitab Al-Jurumiyah memiliki pengaruh perbedaan melalui uji pre-tes dan post-test yang mempunyai hasil pengujian uji th (t hitung) sebesar 8,20 sedangkan uji $t \mathrm{t}$ ( $\mathrm{t}$ tabel) sebesar 1,70. Maka terdapat pengaruh perbedaan yang signifikan antara variabel $\mathrm{X}$ dengan variable $\mathrm{Y}$. Adapun besaran kontribusi variabel $\mathrm{X}$ tentang implementasi metode qiyâsiy terhadap variabel $\mathrm{Y}$ tentang kemampuan santri dalam memahami kitab Al-Jurumiyah menunjukkan sebesar 67,24\%. Dan masih ada sekitar $32,76 \%$ dipengaruhi oleh faktor-faktor lainnya yang tidak diteliti dalam penelitian ini. Dengan demikian dapat disimpulkan, bahwa makin baik implementasi metode qiyâsiy ada pengaruh dengan naik kemampuan santri dalam memahami kitab Al-Jurumiyah dan sebaliknya makin tidak baik implementasi metode qiyâsiy ada pengaruh dengan makin rendahnya kemampuan santri dalam memahami kitab Al-Jurumiyah. Hasil penelitian ini menginformasikan bahwa implementasi metode qiyâsiy ada pengaruh perbedaan secara positif dan signifikan dengan kemampuan santri dalam memahami kitab Al-Jurumiyah di Pesantren AlThahiriyah Lontar Baru kota Serang Provinsi Banten. 


\section{E. Simpulan}

Setelah dilakukan penyajian data dan pembahasan hasil penelitian, maka bisa ditarik kesimpulan dari data instrumen angket implementasi metode qiyâsiy didapat pelaksanaan metode qiyâsiy pada pengajian Al-Jurumiyah yang dilakukan Kyai/ Ustadz di pondok pesantren Ath-Thahiriyah didapat secara umum rerata dalam kategori baik atau sering dalam tahapan-tahapan pembelajaran Al-Jurumiyah yang berdasar teori metode qiyâsiy dapat dinyatakan kategori nilai: sering/baik dan nilai rerata prosentasenya adalah $50,7 \%$. Adapun hasil pengujian analisis parsial dari kemampuan santri dalam memahami kitab Al-Jurumiyah dalam penjelasan di atas menunjukkan bahwa kemampuan santri dalam memahami kitab Al-Jurumiyah dapat dikategorikan sangat baik atau sangat tinggi kemampuannya. Kemudian implementasi metode qiyâsiy mempunyai hubungan sebesar $0,01 \%$ dengan naik turunnya kemampuan santri dalam memahami kitab Al-Jurumiyah menunjukkan tidak ada hubungan yang signifikan dengan implementasi metode qiyâsiy dalam pembelajar kitab Al-Jurumiyah.

Terdapat hubungan yang positif dan signifikan antara metode sorogan dan metode bandungan secara bersama-sama dengan kemampuan membaca kitab kuning di Pesantren Ath-Thahiriyyah Lontar Batu Kota Serang. Dengan demikian, metode sorogan dan metode bandungan secara bersama-sama mempunyai hubungan dengan peningkatan kemampuan membaca kitab kuning. Peningkatan metode sorogan dan metode bandungan akan diikuti dengan peningkatan kemampuan membaca kitab kuning. 


\section{Daftar Pustaka}

Aliyah, Aliyah. "Pesantren Tradisional Sebagai Basis Pembelajaran Nahwu Dan Sharaf Dengan Menggunakan Kitab Kuning." Al-Ta'rib : Jurnal IImiah Program Studi Pendidikan Bahasa Arab IAIN Palangka Raya 6, no. 1 (2018). https://doi.org/10.23971/altarib.v6i1.966.

Azra, Azyumardi. Pendidikan Islam: Tradisi dan Modernisasi Menuju Milenium Baru. Jakarta: Logos Wacana Ilmu, 1995.

Effendy, Ahmad Fuad. Metodologi Pengajaran Bahasa Arab. Malang: Misykat, 2009.

Hosnan, M. Pendekatan Saintifik dan Kontekstual dalam Pembelajaran Abad 21: Kunci Sukses Implementasi Kurikulum 2013. Bogor: Ghalia Indonesia, 2014.

Khithir, Mahmud Rusydi. Thuruq Tadris al-Lughah al-'Arabiyyah wa alTarbiyah al-Diniyyah fi Dhau'i al-Ittijahat al-Haditsah. Kairo: Daar alMa'rifah, 1983.

Khush, Ahmad al-. al-Ghalayaini Nahwiyyu al-'Ashr. Damaskus: alMathba'ah al-'Ilmiyyah, 1988.

Masyhud, M. Sulthon, dan M. Khusnurridlo. Manajemen Pondok Pesantren. Jakarta: Diva Pustaka, 2005.

Muhlis, Achmad. "Pengembangan Model Pembelajaran Qawaid Sharraf dengan Pendekatan Qiyasiyah di MTs Negeri Sumber Bungur Pamekasan." NUANSA: Jurnal Penelitian IImu Sosial dan Keagamaan Islam 13, no. 1 (2016). https://doi.org/10.19105/nuansa.v13i1.920.

Nafi', M. Dian, Abd A'la, Hindun Anisah, Abdul Aziz, dan Abdul Muhaimin. Praksis Pembelajaran Pesantren. Yogyakarta: PT. LKiS Pelangi Aksara, 2007.

Philips, June K. Building on Experence, Building for Succes. Lincolnwood: National Teks Book, 1979.

Richards, Jack C., dan Theodore S. Rodgers. Approaches and Methods in Language Teaching: A Description and Analysis. Cambridge University Press, 1986.

Sa'adah, Neli, dan Khasan Aedi. "Pengaruh Metode Deduktif dengan Menggunakan Media Kartu dalam Memahami Jumlah Fi'liyah (Mahasantri Ma'had Al-Jami'ah IAIN Syekh Nurjati Cirebon)." ElIbtikar 7, no. 2 (2018). https://doi.org/10.24235/ibtikar.v7i2.3335.

Sodiq, Akhmad. Bahan Ajar PLPG: Metodologi Pembelajaran Agama Islam. Jakarta: FITK UIN Syarif Hidayatullah, 2011. 
Thu'aimah, Rusydi Ahmad, dan Muhammad al-Sayyid Manna'. Tadris al'Arabiyyah fii al-Ta'liim al-'Amm: Nazhariyyat wa Tajarib. Kairo: Daar al-Fikr al-'Arabii, 2000.

Ushaili, 'Abd al-'Aziz ibn Ibrahim al-. al-Nazhariyyat al-Lughawiyyah wa alNafsiyyah wa Ta'lim al-Lughah al-'Arabiyyah. Riyadh: Maktabah alMalik Fahd al-Wathaniyyah, 2000.

Wahab, Muhbib Abdul. Epistimologi dan Metodologi Pembelajaran Bahasa Arab. Jakarta: Lembaga Penelitian UIN Syarif Hidayatullah, 2008. 